\title{
Removal of Appendiceal Fecalith with Colonoscopy
}

\author{
Apendisyal Fekalitin Kolonoskopi ile Çıkarılması
}

Mevlüt Kurt, Emrah Poşul, Güray Can, Bülent Yılmaz, Uğur Korkmaz

Abant Izzet Baysal University, Faculty of Medicine, Department of Gastroenterology, Bolu, Turkey

\begin{abstract}
It is generally accepted that fecalith is the main reason of acute appendicitis. In this report, we represented a case that established a fecalith in the appendicial lumen at the colonoscopic investigation. Clinical features of the patient have resolved after removal of the appendicular fecalith with colonoscopy. Patient was prevented from probable appendicitis, which will develop, with colonoscopic intervention.
\end{abstract}

Key Words: Appendiceal fecalith , colonoscopy, treatment

Received: 10.03 .2015

Accepted: 06.06.2016

\section{ÖZET}

Apendisyal fekalit akut apandisitin temel nedeni olarak kabul edilmektedir. Karın ağrısı nedeniyle yapılan kolonoskopik incelemede apendiks lümeninde fekalit saptanan bir olgu sunulmuştur. Kolonoskopik müdahale ile fekalit çıkarıldıktan sonra hastanın kliniği gerilemiştir. Muhtemel bir akut apandisit tablosu yapılan mudahale ile önlenmiştir.

Anahtar Sözcükler: Apendisyal fekalit, kolonoskopi, tedavi

Geliş Tarihi: 03.10.2015

Kabul Tarihi: 06.06.2016

\section{INTRODUCTION}

The fecalith is a rigid stool particle collection seen in the appendicular lumen (1). It is generally accepted that fecalith is the main etiology of acute appendicitis in adults (2). In addition, it may cause chronic appendicitis which is an atypical and chronic presentation of appendicitis believed to result from partial and transient obstruction of the appendix (3). Furthermore, patients may present with recurrent right iliac fossa pain (4). In this report, a case with recurrent abdominal pain that resolved after removal of the appendicular fecalith during colonoscopy is presented.

\section{CASE REPORT}

A 29-year-old women presented to our gastroenterology unit with a complaint of abdominal pain. She had been having intermittent periumblical and epigastric pain for three months. Physical examination revealed no abnormal findings, except for epigastric and periumblical tenderness without guarding or rebound. Laboratory results and abdominal ultrasonography of the patient were normal. She had empirically used proton pump inhibitor and Pinaverium bromide which were given by another physician for the same complaint. She did not notice any improvement in her symptoms.

Address for Correspondence / Yazışma Adresi: Güray Can, MD, Abant Izzet Baysal University, Faculty of Medicine, Department of Gastroenterology, PK: 14280, Golkoy, Bolu, Turkey Fax: +90 3742534615 E-mail: dr guraycan@yahoo.com

(CTelif Hakkı 2016 Gazi Üniversitesi Tıp Fakültesi - Makale metnine http://medicaljournal.gazi.edu.tr/ web adresinden ulaşılabilir.

(C) Copyright 2016 by Gazi University Medical Faculty - Available on-line at web site http://medicaljournal.gazi.edu.tr/

doi:http://dx.doi.org/10.12996/gmj.2016.47 
She underwent upper gastrointestinal (GI) endoscopy and colonoscopy. Upper GI endoscopy revealed antral gastritis, biopsy specimens were taken from gastric antrum. Colonoscopy was normal except for liquid stool in the opening of the appendix (Fig. 1a). It was cleared with washing and suctioning. However, as we came to the entrance of the appendiceal lumen by the tip of the endoscope, a fecalith was seen (Fig. 1b). When we pulled back the colonoscope, the fecalith remained in the appendiceal lumen, and a purulent material was forthcoming (Fig. 1c). We were unable to remove the fecalith with suction, biopsy forceps and polypectomy snare. It was therefore removed by diluting and washing with $180 \mathrm{ml}$ of warm water by using a $60 \mathrm{ml}$ syringe (Fig 1d). Histological examination of the antral biopsies revealed Helicobacter pylori ( $\mathrm{Hp}$ ) gastritis. A proton pump inhibitor plus amoxicillin, and clarithromycin were given for eradication of $\mathrm{Hp}$. She was seen in followup two months later and reported no recurrence of the symptoms. Hp stool antigen test was also negative.

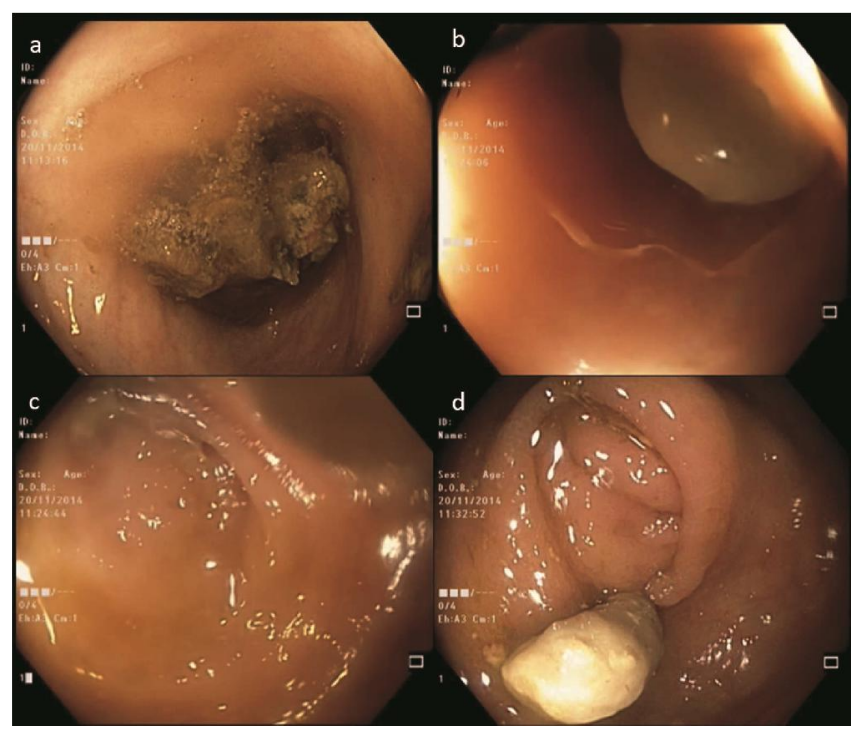

Figure 1. Endoscopic views. Liquid stool on the appendiceal orifice (a). After aspiration of this liquid stool, the colonoscope enter into to the orifice of the appendix and confirmed a fecalith in the lumen of appendix (b). Pus flowing from the orifice while the colonoscope is being pulled back (c). A fecalith was seen in the cecum (d).

\section{DISCUSSION}

Acute nonperforated or perforated appendicitis after colonoscopy were reported previously in the literature (5). Our case is the first in the literature. In fact, if we had not aspirated the liquid stools, we would not have seen the fecalith in the appendiceal lumen. We have learned from this case that fecalith can be removed by washing with warm water during a colonoscopy. In our case, we proposed that the patient was prevented from developing appendicitis in the near future $(1,2)$.

\section{Conflict of interest}

No conflict of interest was declared by the authors

\section{REFERENCES}

1. Engin O, Muratli A, Ucar AD, Tekin V, Calik B, Tosun A. The importance of fecaliths in the aetiology of acute appendicitis. Chirurgia (Bucur) 2012; 107: 756-60.

2. Ramdass MJ, Young Sing Q, Milne D, Mooteeram J, Barrow S. Association between the appendix and the fecalith in adults. Can J Surg 2014; 57: 2014. 3. Shah SS, Gaffney RR, Dykes TM, Goldstein JP. Chronic appendicitis: an often forgotten cause of recurrent abdominal pain. Am J Med 2013; 126: e78.

4. Grimes C, Chin D, Bailey C, Gergely S, Harris A. Appendiceal faecaliths are associated with right iliac fossa pain. Ann R Coll Surg Engl 2010; 92: 61-4.

5. Pellish R, Ryder B, Habr F. An unusual complication: postcolonoscopy appendicitis. Endoscopy 2007; 39(Suppl 1): E138. 